\title{
Prevalence and clinico-pathological parameters of PPR infected goats and their response to antibiotic treatment at Panchlaish, Chittagong, Bangladesh.
}

\author{
Naznin $\mathrm{M}^{1}$, Ahaduzzaman $\mathrm{M}^{1}{ }^{*}$, Chowdhury $\mathrm{S}^{2}$, Biswas $\mathrm{PK}^{3}$ \\ ${ }^{1}$ Department of Medicine and Surgery; ${ }^{2}$ Department of Pathology and Parasitology; ${ }^{3}$ Department of \\ Microbiology; Chittagong Veterinary and Animal Sciences University, Khulshi-4225, Chittagong, Bangladesh.
}

[Received: May 02, Accepted: July 08, 2014]

\begin{abstract}
The present study was conducted in the Panchlaish Upazilla Veterinary Hospital of Chittagong district during the period of July to September, 2013 to find out the prevalence and clinico-pathological findings of Peste des petits ruminants (PPR) in goats, and to observe the response of PPR-goats to different treatments. During the course of study 202 goats were examined of which 98 were PPR positive. Diagnosis of a PPR case was made following the clinical examinations. The results showes that the median age of PPR-goats was higher compared with the healthy ones. The median per-rectum temperature, heart and respiratory rates were also higher in the the PPR-postive goats. No significant difference was seen on its prevalence in goats belonging to Black Bengal or Jamunapari breeds. Its occurence was also evenly seen in each of the three months- July, August and September. But, prevalence of PPR was significantly higher in the nonvaccinated goats. Some hematological parameters except neutrophil count was lower in PPR goats. The recovery rate from clinical signs was higher in goats treated with parenteral administration of oxytetracycline.
\end{abstract}

Key words: antibiotic, blood analysis, goats, PPR, Clinical parameters

\section{INTRODUCTION}

Peste des petits ruminants (PPR) is an acute or subacute, contagious viral disease of small ruminants emphasized for goats of Bangladesh [1]. Both sheep and goats become affected although goats are often more severely affected than sheep [2]. The risk of PPR is $62.5 \%$ in domestic small ruminants around the globe [3]. Transmission occurs by close contact, inhalation of aerosol produced by direct and indirect approach [4]. The disease is characterized by high fever, necrotic stomatitis, catarrhal inflammation of the ocular and nasal mucosae, dyspnea, diarrhea and death [1]. In epidemic areas, morbidity rate has been estimated between $80-90 \%$ and mortality between $50-80 \%$ [5]. Necropsy of diseased goats revealed congested and consolidated pneumonic lungs, generalized enlargement of lymphnodes accompanied with necrosis and congestion of some lymphnodes, atrophied congested spleen and hemorrhagic gastroenteritis [6]. Excluding clinical signs, history and complete blood count the PPR can also be diagnosed by using Heamagglutination test (HA), Compliment fixation test (CFT), Immunoelectro-osmo-precipitation test and Enzyme linked immuno-sorbent assay (ELISA) [7]. Determination of hematology of animals helps veterinarians to confirm clinical diagnosis, estimate the severity of cases, administer appropriate treatment, and evaluate outcomes [8].

The disease was shown to be more severe among young animals, and, therefore, causes high economic losses in these animals [9]. On the other hand, its morbidity and mortality rates rise with presence of secondary infections such as pox, ecthyma, E. coli, pasteurellosis, coccidiosis and cryptosporidiosis infections [10].There is no specific treatment and control is possible only with vaccination. Therefore, the present study was carried out to find the overall prevalence of PPR in relation with breed, age, sex, season and immune status of goats and to determine hematological parameters and therapeutic outcomes in goats of a coastal area of Bangladesh.

\section{MATERIALS AND METHODS}

\section{Study area and duration}

The study was carried out for three months period from July to September, 2013 in the Upazilla Veterinary Hospital, Panchlaish, Chittagong, Bangladesh.

\section{Population and tools used for data collection}

The study was conducted on natural PPR infected goats of various age, sex and breed that were brought to the hospital over the study period. A total of 202 goats were registered for treatments of which 98 were diagnosed with PPR. Close inspection was performed properly in order to observe the presenting signs.

\section{Medication:}

For observing the treatment efficacy the PPR goats were divided into three groups:

Group I: treated with Diadin (Sulphadimidine-Na) (Renata Ltd., Bangladesh) + Antihista vet (Pheneramine meleate) (Square Pharma, Bangladesh) + Renalyte (ORS) (Renata Ltd., Bangladesh). 
Group II: treated with Renamycin- $100^{\circledR}$ (Oxytetracycline) (Renata Ltd., Bangladesh) + Antihista vet ${ }^{\circledR}$ (Pheneramine meleate) + Renalyte $^{\circledR}$ (ORS) and

Group III: treaed with oral or gut acting sulphonamide (Cotrim vet ${ }^{\circledR}$ ) (Square Pharma, Bangladesh) + Renalyte ${ }^{\circledR}$ (ORS).

A response to a treatment was measured by recovery from the clinical illness.

\section{Hematological analysis:}

Hematological analysis of a sample was performed on an autohemolyzer within 24 hours of collection of a blood sample in the Department of Physiology, Biochemistry and Pharmacology at CVASU according to the biochemical analyzer manual (Humalyzer 3000, Germany ${ }^{\mathrm{R}}$ ). In total blood was collected from 20 PPR-goats whose hematological parameters were compared with the values of those from 20 healthy goats.

\section{Statistical analysis}

All data were collated and stored into a spreadsheet (Microsoft office excel-2007, USA). The Excel spread sheet was imported to SAS version 9.2 for further analysis. Categorical variables; sex, breed, vaccination status, season were tested with Chi square test to estimate the effect of the variables on the outcome (PPR) and continuous variables; age, temperature, heart rate, respiratory rate were tested with t-test where the null hypothesis was that there was no difference in mean between positive and negative groups of animals. Descriptive analysis was done by means of histogram and boxplot. An association was regarded as significant if the $\mathrm{p}$-value was $<0.05$.

\section{RESULTS}

\section{Demographic statistics of PPR-positive goats}

A total of 202 goats belonging to different breeds were brought to the hospital by their owners/attendants, of which 98 were found PPRpositive, by thorough clinical examinations and in few cases with post mortem investigations. The median age of PPR-goats was higher compared with the healthy ones (Figure 1). Like age, the median per-rectum temperature $\left({ }^{\circ} \mathrm{F}\right)$ was also higer in the PPR-goats (Figure 2); heart rate and respiratory rate were also higher in the PPR-goats compared with the healthy ones (Table 2).

The occurrences PPR in goats associated with the categorical variables: breed of goats, sex, satatus of PPR-vaccination and month of occurrence are in Table 1. PPR was evenly distributed in Black Bengal and Jamunapai gaots ( $p>0.05)$ and in male and female goats. It could be evenly seen in any of the three months observed - July, August and Septmber. However its occurence was significantly higher in the non-vaccinated compared with the vaccinated ones $(p<0.001)$ (Table 1$)$.

PPR associated with different continuous variables asseessed

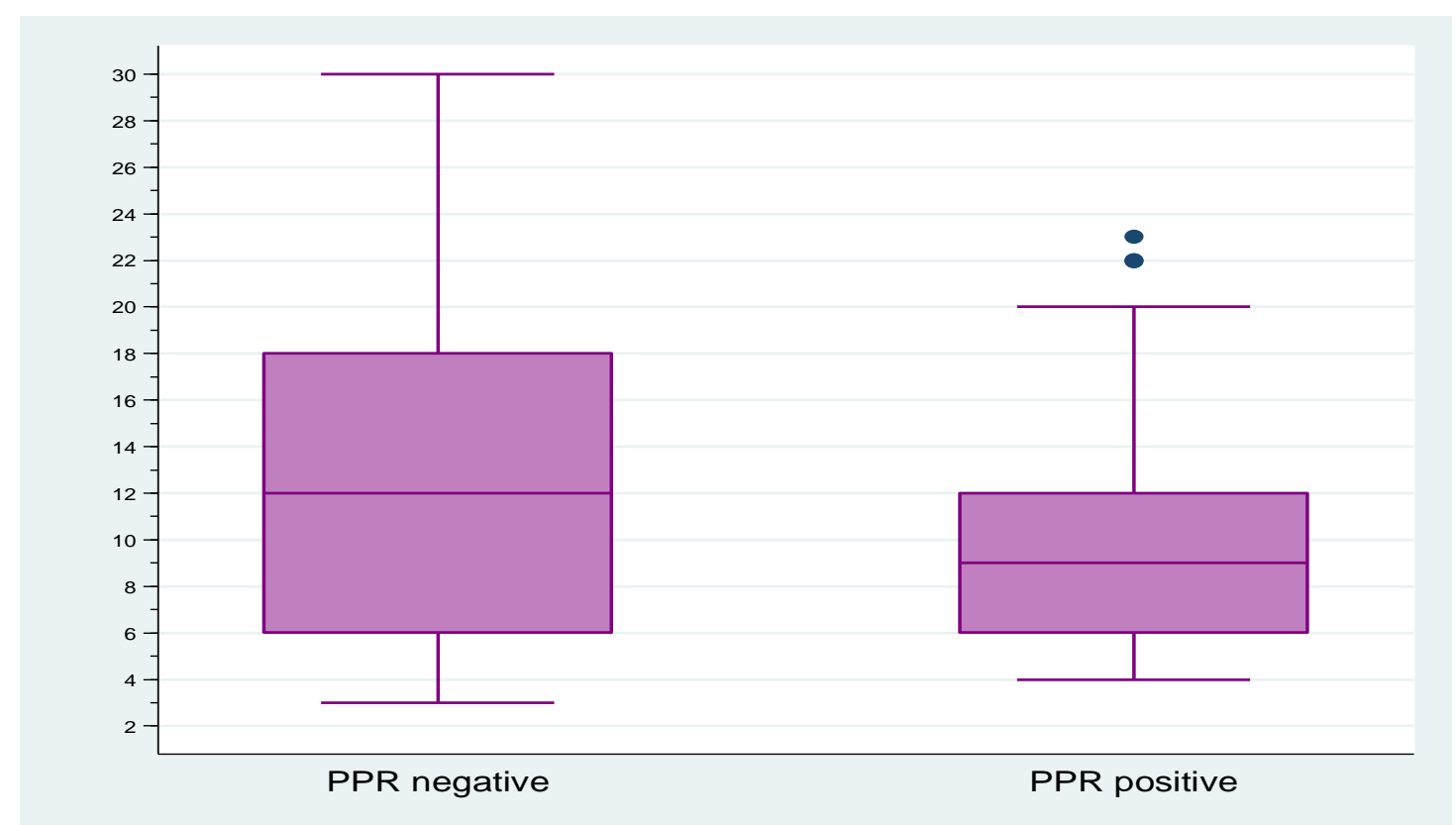

Figure 1: shows that- Among PPR negative animals, minimum age was 3 months and maximum age was 30 months. $25 \%$ animal were equal or below 6 months of age and $75 \%$ animals were equal or below 18 months of age. The median age for this group of animals was 12 months. Similarly, among PPR positive animals, minimum and maximum ages were 6 months and 20 months, respectively. 25\% animals were equal or below 6 months and 75\% animals were equal or below 12 months of age. The median age for this group of animals was 9 months. 
Table 2 is presented with the occurrences PPR in goats associated with the variables: age (in month), temperature, heart rate and respiratory rate. The mean value of temperature in PPR-goats was

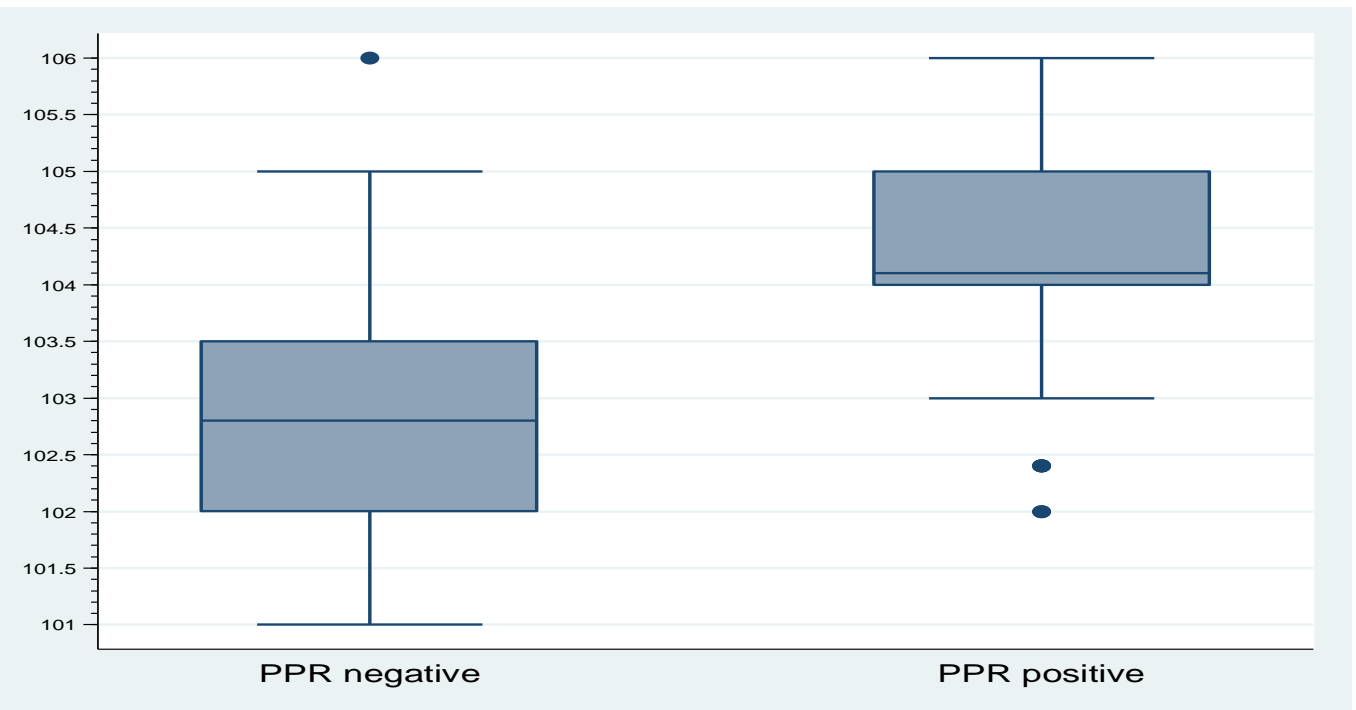

Figure 2: shows that- Among PPR negative animals, minimum temperature was $101^{\circ} \mathrm{F}$ and maximum temperature was $105^{\circ} \mathrm{F} .25 \%$ animal were equal or below $102^{\circ} \mathrm{F}$ of temperature and $75 \%$ animals were equal or below $103.5^{\circ} \mathrm{F}$ of temperature. The median temperature for this group of animals was $102.8^{\circ} \mathrm{F}$. Similarly, among PPR positive animals, minimum and maximum temperatures were $103^{\circ} \mathrm{F}$ and $106^{\circ} \mathrm{F}$, respectively. $25 \%$ animals were equal or below $104^{\circ} \mathrm{F}$ and $75 \%$ animals were equal or below $105^{\circ} \mathrm{F}$ of temperature. The median temperature for this group of animals was $104.1^{\circ} \mathrm{F}$.

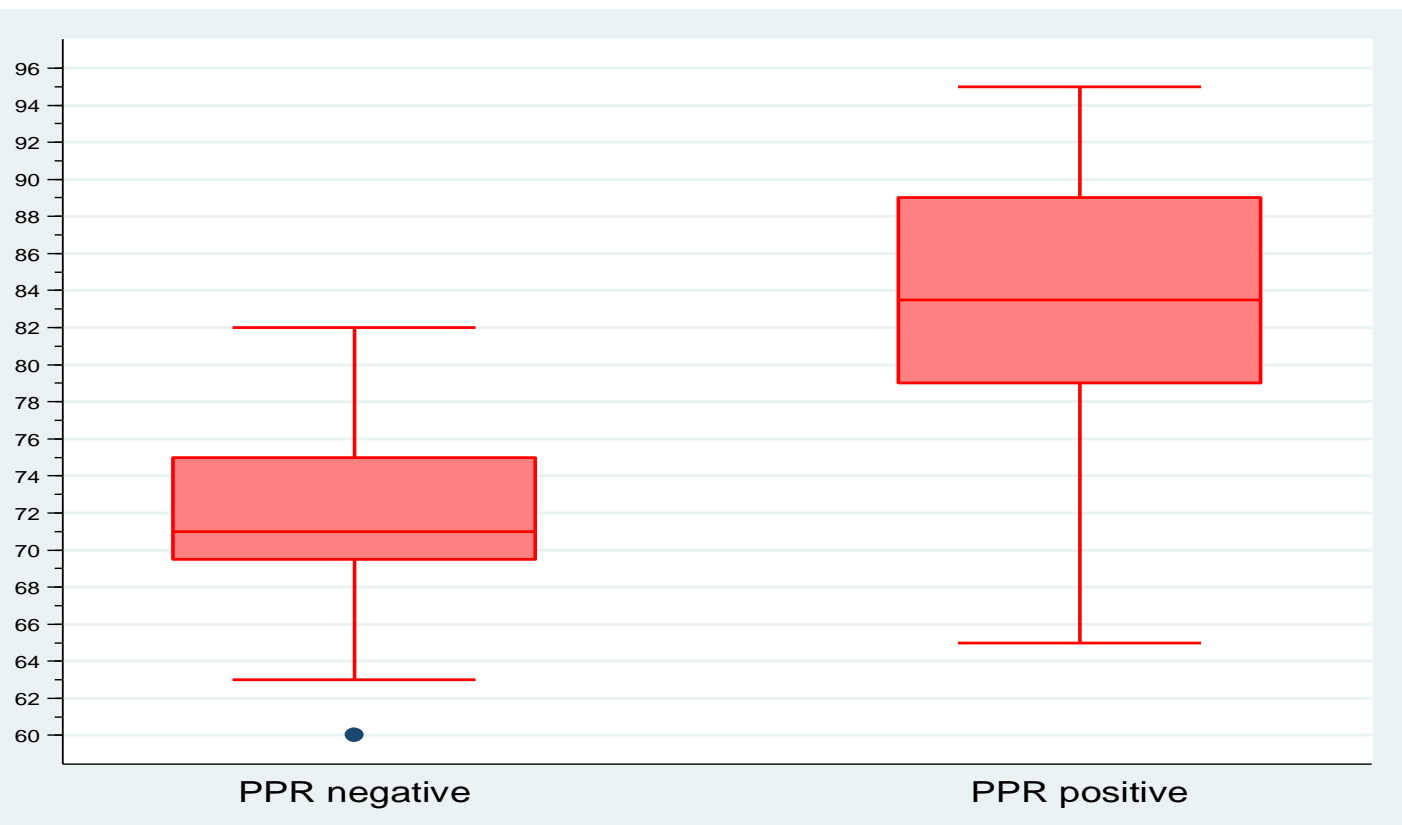

Figure 3: shows that- Among PPR negative animals, minimum heart rate was 63 and maximum heart rate was $82.25 \%$ animal were equal or below 69 of heart rate and $75 \%$ animals were equal or below 75 of heart rate. The median heart rate for this group of animals was 71. Similarly, among PPR positive animals, minimum and maximum heart rates were 65 and 95, respectively. 25\% animals were equal or below 79 and $75 \%$ animals were equal or below 89 of heart rate. The median heart rate for this group of animals was 83 . 
$104.8^{\circ} \mathrm{F}$, significantly higher to those that were PPRnegative $(p<0.001)$. The mean heart rate and respiratory rates in the PPR-goats were 83 and 36 per minute, significantly higher to the PPR-negative gaots $(p<0.001)$.

\section{Comparison of hematological pictures}

Table 3 shows the hematological pictures of 20 PPR affected goats compared with 20 normal goats. In diseased animal the mean values of some key hematological parameters - $\mathrm{Hb}(8.20 \mathrm{gm} \%)$, PCV (18.90), TEC $\left(9.50\right.$ million $\left./ \mathrm{mm}^{3}\right)$, TLC $(9.80$ thousand $/ \mathrm{mm}^{3}$ ), ESR (0 hour), lymphocyte (41.20\%), monocyte $(3.80 \%)$, eosinophil $(3.90 \%)$, basophil $(0.90 \%)$ were proportionately but not significantly lower, and the differential count of neutrophils in PPR-positive goats were higher compared with the healthy animals (Figure 5).

\section{Response of PPR cases to different treatments}

The response of PPR-goats, in three groups showed that, 58\% PPR-positive goats survived when they were treated with parenteral administration of oxytetracycline. The response to the use of parenteral or gut active sulfonamides was about 28 and $23 \%$, respectively, significantly lower to the rate achieved by the use of oxytetracycline (Table 4).

\section{DISCUSSION}

Breedwise prevalence of PPR was $52 \%$ in Black Bengal, $49 \%$ in Jamuna Pari and $43 \%$ in Cross breed goats. Apparently the disease does not differ significantly $(\mathrm{P}>0.05)$ in association with breeds but in Black Bengal goats the percentage $(\%)$ of the occurance of disease was comparatively higher. This findings are in line with previous finding that the prevalence of PPR was higher in indigenous Black Bengal $(27.13 \%)$ goats than Jamunapari $(11.81 \%)$ and exotic breeds $(9.68 \%)$ [11]. This result is also similar with finding of previous reports[12]; it is also reported that Black Bengal goats are more susceptible to PPR than Jamunapari (31.78\%) [1].

The disease was almost evenly distributed in both male and female goats, is supported by previous report [13]. But the sex of of goats had no effect on the development of PPRV antibodies [14].

According to vaccination status, $66 \%$ prevalence was recorded in non-vaccinated goats and $26 \%$ prevalence in vaccinated goats. This result supports the early report where the prevalence of PPR is higher $(66.40 \%)$ in non-vaccinated as compare with vaccinated (19.56\%) animals [1]. A higher prevalence of PPR in the non vaccinated goat population was also found earlier [15]. In the present study, the disease differed significantly ( $\mathrm{P}<0.05)$ between vaccinated and non vaccinated goats, suggesting that non vaccinated animals are at a higher risk to PPR. Vaccination against PPR leads to decrease in the disease prevalence but cannot protect absolutely [16]. This efficacy of PPR vaccine in reducing the prevalence of PPR was also reported [17].

The disease was a bit higher during the month of

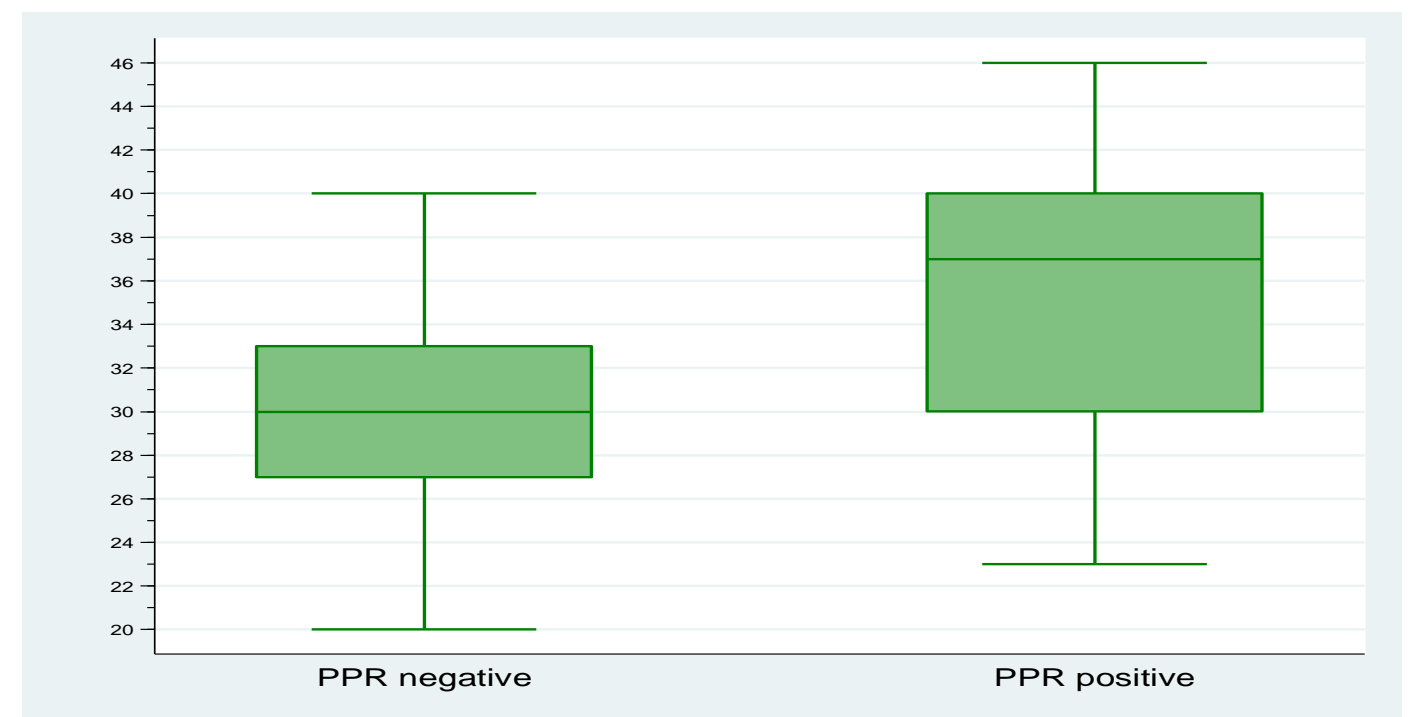

Figure 4 shows that- Among PPR negative animals, minimum respiratory rate was 20 and maximum respiratory rate was $40.25 \%$ animal were equal or below 27 of respiratory rate and $75 \%$ animals were equal or below 33 of respiratory rate. The median respiratory rate for this group of animals was 30. Similarly, among PPR positive animals, minimum and maximum respiratory rate were 23 and 46, respectively. $25 \%$ animals were equal or below 30 and $75 \%$ animals were equal or below 40 of respiratory rate. The median respiratory rate for this group of animals was 37 . 
August (54\%), July (47\%) and lowest in September (42\%). Aparently, the disease does not differ significantly ( $\mathrm{P}>0.05)$ between the months, but a comparative higher occurrence of PPR was observed
[18].The increased susceptibility of young goats were might be due to malnutrition, poor immunity and poor management systems [11].

The median temperature recorded in this

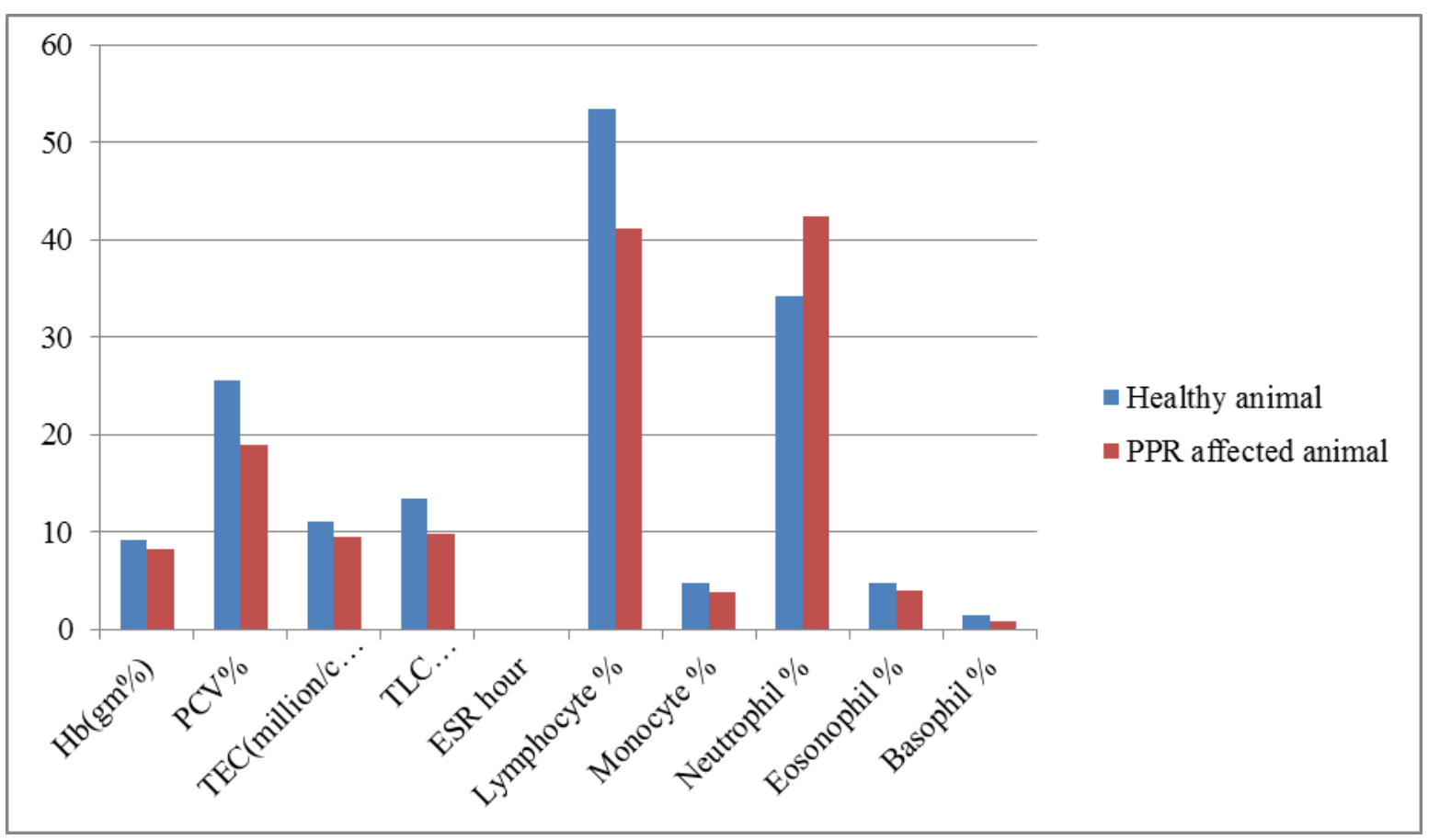

Figure 5: Hematological pictures of PPR-positive and negative goats observed in the study

in the Rainy season [12].

It was reported previously that the age group between 4 to 12 months was more prone to PPR than older (>1 year) also assessed that the disease was most prevalent in the goats less than one year of age investigation was $104.83^{\circ} \mathrm{F}$. Similar higher temperature was described previously [6]. This study also shows a higher heart rate and respiratory rate in PPR positive goats than negative goats $(\mathrm{P}<0.05)$. Higher heart rate may be the results of age of the

Table 1: The frequencies of occurrences of PPR associated with different categorical variables assessed in the study

\begin{tabular}{|c|c|c|c|c|c|}
\hline Variables & Level & $\begin{array}{l}\text { Number of } \\
\text { observation }\end{array}$ & $\begin{array}{l}\text { PPR positive } \\
\mathrm{N}(\%)\end{array}$ & $\begin{array}{l}\text { Chi square } \\
\text { value }\end{array}$ & $P$ value \\
\hline \multirow[t]{3}{*}{ Breed } & Black Bengal & 87 & $45(52)$ & 1.02 & 0.59 \\
\hline & Cross & 47 & $20(43)$ & & \\
\hline & Jamuna Pari & 68 & $33(49)$ & & \\
\hline \multirow[t]{2}{*}{ Sex } & Female & 66 & $36(55)$ & 1.42 & 0.23 \\
\hline & Male & 136 & $62(46)$ & & \\
\hline \multirow[t]{2}{*}{ Vaccination } & No & 114 & $75(66)$ & 31.26 & $<0.001$ \\
\hline & Yes & 88 & $23(26)$ & & \\
\hline \multirow[t]{3}{*}{ Month of the year } & July & 83 & 41 (49) & 0.28 & 0.86 \\
\hline & August & 64 & $32(50)$ & & \\
\hline & September & 55 & $25(45)$ & & \\
\hline
\end{tabular}

Table 2: Comparison of mean values of different continuous variables in PPR- positive and PPRnegative goats

\begin{tabular}{llllll}
\hline Variables & $\begin{array}{l}\text { Disease status of } \\
\text { the goat }\end{array}$ & Mean & SE & $95 \%$ CI & p-value \\
\hline Age (month) & PPR negative & 13.0 & 0.71 & $11.59-14.42$ & 0.002 \\
& PPR positive & 9.84 & 0.45 & $8.95-10.74$ & \\
Temperature & PPR negative & 102.67 & 0.10 & $102.62-103.02$ & $<0.001$ \\
& PPR positive & 104.83 & 0.08 & $104.03-104.98$ & \\
Heart rate & PPR negative & 72.03 & 0.41 & $71.22-72.88$ & $<0.001$ \\
& PPR positive & 83.00 & 0.72 & $81.54-84.45$ & \\
Respiratory rate & PPR negative & 30.4 & 0.46 & $29.48-31.34$ & $<0.001$ \\
& PPR positive & 35.54 & 0.57 & $34.41-36.71$ & \\
\hline
\end{tabular}


animal, severity of dehydration and nutritional status as supported by previous report of PPR-goats [19]. On the other hand respiratory rate mainly increases in PPR-goats that suffer from chronic pneumonic condition [19].

The values of all hematological parameters decreased in the PPR-affected goats compared to healthy goats except neutrophil counts. Total erythrocyte counts (million $/ \mathrm{mm}^{3}$ ) and $\mathrm{Hb}(\mathrm{gm} \mathrm{\% )}$ ) were similar in both the PPR-infected and healthy goats, and PCV (\%) decreased. The $\mathrm{Hb} \%$ and PCV (\%) reflect the downturn of the TEC counts. ESR count was $0 \mathrm{~mm}$ in $1^{\text {st }}$ hour in both cases. Total leukocyte counts were higher in healthy goat as compared to affected goats, though this value did not cross the normal limit. The counts for neutrophils were significantly higher in the PPRV-infected group. In contrast, lymphocyte counts in the PPRV-infected goats were lower than healthy goats $(\mathrm{P}<0.05)$. Monocyte, Eosinophil and Basophil counts were lower in PPRV-infected goats than in healthy goats [10].

The percentage response of treatment towards parenteral $(\mathrm{I} / \mathrm{M})$ use of oxytetracycline was higher $(58 \%)$ than the use of parenteral (I/M) and/or oral/gut acting sulphonamide $(23 \%)$. This is similar to the previous findings, who reported that the percentage of response to treatment from parenteral (I/M) oxytetracycline use was high $(33.87 \%)$ than parenteral (I/M) sulphonamide $(31.58 \%)$ and oral/gut active sulphonamide (16.00\%) [12].

\section{CONCLUSION}

The median age of PPR-goats might be higher compared with the healthy ones in the coastal areas in Bangladesh. Clinically, the median per-rectum temperature is higher in the PPR-postive goats similar to heart and respiratory rates. PPR is evenly distributed in both Black Bengal and Jamunapari goats, and in male and female goats. Its occurence can evenly be seen in each of the three monthsJuly, August and September. However, PPR occurence is significantly higher in the nonvaccinated goats. Some hematological parameters might be lower in PPR-goats compared with the healthy ones, but neutrophil count might be higher in PPR-positive goats. Finally, Oxytetracycline might be used to treat the secondary bacterial infection in PPR goat to save the life with cost effective approach.

\section{ACKNOWLEDGEMENT}

We would like to thanks ULO, Panchlaish Upazilla Veterinary Hospital of Chittagong for his intense support to conduct the research work and the animal owners for their eagerness in regular follow-up of animals and active participation in record keeping.

Table 3: Comparison of Hematological pictures (Mean) of healthy and PPRV affected goat

\begin{tabular}{cccccc}
\hline SL & Parameters & Healthy goat & \multicolumn{3}{c}{ PPR affected goat } \\
NO & & Mean & Min-Max & Mean & Min-Max \\
\hline 1 & Hb (gm \%) & 9.10 & $6.50-12.50$ & 8.20 & $6.80-12.00$ \\
2 & PCV (\%) & 25.60 & $16-32$ & 18.90 & $14.00-29.00$ \\
3 & TEC & 11.10 & $7.56-14.70$ & 9.50 & $6.66-13.50$ \\
& (million/mm3) & & & & \\
4 & TLC & 13.45 & $8.90-16.20$ & 9.80 & $7.00-12.30$ \\
& (thousand/mm3) & & & & \\
5 & ESR & 0 & $0-0$ & 0 & 0 \\
& (hour) & & & & \\
6 & DLC (\%) & - & - & - & - \\
a & Lymphocyte (\%) & 53.40 & $37-70$ & 41.20 & $32-55$ \\
b & Monocyte (\%) & 4.80 & $1-7$ & 3.80 & $1-6$ \\
c & Neutrophil (\%) & 34.20 & $25-42$ & 42.40 & $33-56$ \\
d & Eosinophil (\%) & 4.80 & $3-7$ & 3.90 & $2-6$ \\
e & Basophil (\%) & 1.40 & $0-3$ & 0.90 & $0-2$ \\
\hline
\end{tabular}

Table 4: Response of PPR-goats to different treatments (in three groups)

\begin{tabular}{|c|c|c|c|c|c|}
\hline \multirow[t]{2}{*}{ Group } & \multirow[t]{2}{*}{ Drugs used } & \multicolumn{2}{|c|}{$\begin{array}{l}\text { Response to } \\
\text { treatment }\end{array}$} & \multirow[t]{2}{*}{ Total } & \multirow[t]{2}{*}{$\begin{array}{l}\% \text { of response } \\
\text { to treatment }\end{array}$} \\
\hline & & Positive & Negative & & \\
\hline I & $\begin{array}{l}\text { Diadin }^{\circledR} \text { ( Sulphadimidine-Na) + Antihista } \\
\text { vet }^{\circledR}(\text { Pheneraminemeleate })+\text { Renalyte }^{\circledR} \\
\text { (ORS) }\end{array}$ & 13 & 33 & 46 & 28 \\
\hline II & $\begin{array}{l}\text { Renamycin- } 100{ }^{\circledR}(\text { Oxytetracycline })+ \\
\text { Antihista vet }{ }^{\circledR}(\text { Pheneraminemeleate })+ \\
\text { Renalyte }^{\circledR}(\text { ORS })\end{array}$ & 15 & 11 & 26 & 58 \\
\hline II & $\begin{array}{l}\text { Oral or gut acting sulphonamide (Cotrim } \\
\left.\text { vet }^{\circledR}\right)+ \text { Renalyte }^{\circledR} \text { (ORS) }\end{array}$ & 6 & 20 & 26 & 23 \\
\hline
\end{tabular}




\section{REFERENCES}

1. Islam MS, Khan MSI, Kader HA, Begum MR and Asgars MA(2012).Prevalence of PPR of Goat and Their Response to Antibiotic Treatment at Mirzaganj Upazila of Patuakhali Distrtict. J. Environ. Sci. and Nat. Resour. 5(2):181-184.

2. Albina E, Kwiatek O, Minet C, Lancelot R, Servan-de-Almeida R and Libeau G (2013). Peste des petits ruminants, the next eradicated animal disease? Vet. MIcrobiol. 165(1-2):3844.

3. Zahur AB, Ullah A, Hussain M, Irshad H, Hameed A, Jahangir M and Farooq MS (2011). Sero-epidemiology of peste des petits ruminants (PPR) in Pakistan. Prev. Vet. Med. 102:87-92.

4. Mulindwa B, Ruhweza SP, Ayebazibwe C, Mwiine FN, Muhanguzi D and Mukani WO (2011). Peste des Petits Ruminants serological survey in Karamoja sub region of Uganda by competitive ELISA. Vet. World 4(4):149-152.

5. Abubakar M, Jamal SM, ArshedMJ, Hussain M and Ali Q (2009). Peste des petitsruminants virus (PPRV) infection; its association with specie, seasonal variation and geography. Trop. Anim. Health Pro. 41:1197-1202.

6. Khan MR, Haider MG, Alam KJ, Hossain MG, Chowdhury SMZH and Hossain MM (2005). Bangladesh J. Vet. Med. 3(2):134-138.

7. Intizar M, Ahmad MD, Anjum AA and Hanif A (2009). Comaprative efficacy of peste des petits ruminant (PPR) vaccines available in Pakistan in sheep and goats. Pak. Vet. J. 29(4): 202-205.

8. Bafti MS and Mozaffari A (2012). Normal hematological parameters in Iranian cashmere (Raini) goats. Comp. Clin. Path. 21(6):1653.

9. Diallo A, Minet C, LeGoff C, BerheG, Albina E, Libeau $G$ and Barrett T (2007). The threat of peste des petits ruminants: Progress in vaccine developmentfor disease control. Vaccine 25:5591-5597.

10. Aytekin I, Mamak N, Ulucan A and Kalinbacak A (2011). Clinical, haematological, biochemical and pathological findings in lambs with Peste des Petits Ruminants. Kafkas Üniversitesi. Veteriner. Fakültesi. Dergisi.17 (3):349-355.

11. Sarker S and Islam MH (2011). Prevalence and Risk Factor Assessment of Peste des petits ruminants in Goats in Rajshahi, Bangladesh. Vet. World 4(12): 546-549.

12. Gupta SD, Biswas P, Habib S and Debnath NC (2007). Prevalence of PPR in the greater Chittagong district of Bangladesh. g-science. 3(2):36-41.

13. Abdalla SA, Majok AAE, Malik KHand Ali AS (2012). Sero-prevalence of peste des petitsruminants virus (PPRV) in small ruminants in Blue Nile, Gadaref and North Kordofan States of Sudan. J. Public. Health Epi. 4(3):59-64.

14. Iman N, Mesam PK and Omid M (2012). Survey on PPR in Small Ruminants. Ann. Biol. Res. 3(10):4842-4844.

15. El-Yuguda $A D$, Abubakar $M B$, Nabi $A B$, Andrew Aand Baba SS (2009). Outbreak of Peste Des Petits Ruminant in an Unvaccinated Sahel Goat Farm in Maiduguri, Nigeria. Afr. J. Biomed. 12(1): 83-87.

16. Banik SC, Podder SC, Samad MA and Islam MT (2008). Sero surveillance and immunization in sheep and goats against Peste des Petits Ruminants in Bangladesh. Bangladesh J. Vet. Med. 6 (2): 179-183.

17. Das KK, Shil NK andI slam MR (2007).Seroepidemiological investigation on Peste des Petits Ruminants in black Bengal goats. Banglad. J. Microbiol. 24: 143-145.

18. Mahajan S, Agrawal R, Kumar M, Mohan A and Pande N (2013). Incidence of Peste des petits ruminants in nomadic sheep and goat of Jammu region. Vet. World 6(7):384-387.

19. Radostits OM, Gay CC, Blood DC and Hinchcliff KW (2005). Diseases caused by viruses and Chlamydia. P. 12-14.Veterinary Medicine.9th ed. W.B. Saunders Company Ltd, London. 